\title{
Explorations on the total synthesis of $( \pm)$-isoschizogamine using an intramolecular 1,4-dipolar cycloaddition strategy
}

\author{
Albert Padwa,* Drew R. Bobeck and Edwin M. Mmutlane \\ Department of Chemistry, Emory University, Atlanta, GA 30322 \\ E-mail: chemap@emory.edu
}

Dedicated to Franklin A. Davis on the occasion of his 70th anniversary

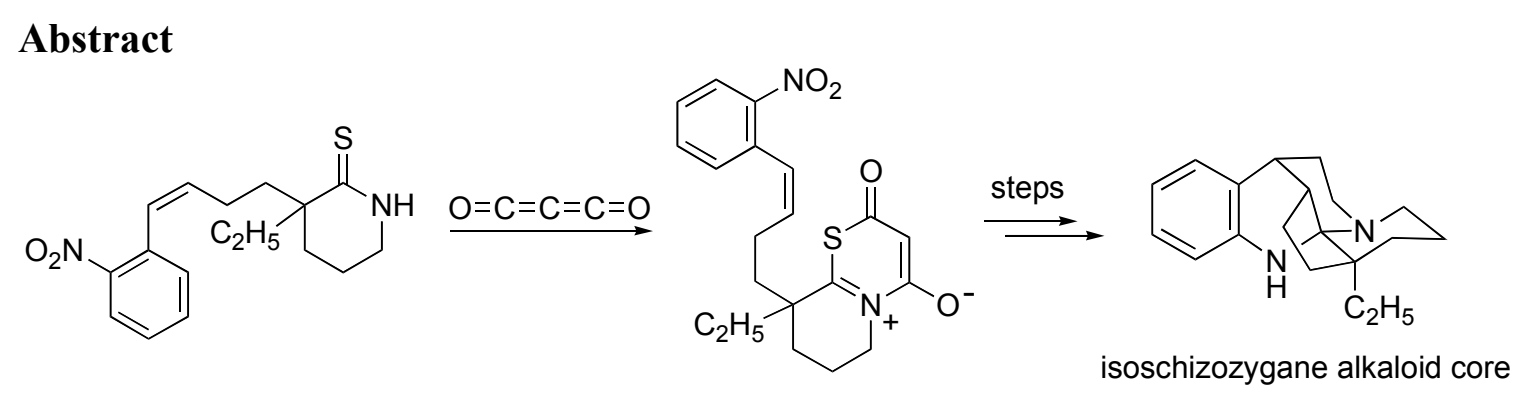

A new strategy for the synthesis of the isoschizozygane alkaloid core has been developed that is based on a 1,4-dipolar cycloaddition reaction of a cross-conjugated heteroaromatic betaine. The required substituted piperidin-2-one needed for the eventual 1,4-dipolar cycloaddition step was prepared using an aza-Claisen rearrangement.

Keywords: 1,4-Dipolar, cycloaddition, cross-conjugated, heteroaromatic, betaine, aza-Claisen, rearrangement

\section{Introduction}

The schizozyganes represent a small group of hexacyclic indoline alkaloids ${ }^{1}$ that were obtained from the twigs of the East African monotypic shrub Schizozygia caffaeoides. ${ }^{2,3}$ In addition to the major alkaloid schizozygine (1), ${ }^{4}$ a pair of minor alkaloids were isolated ${ }^{5}$ and their structures were established as isoschizogaline (2) and isoschizogamine (3) on the basis of extensive NMR studies. ${ }^{3}$ It was postulated that the skeleton of the schizozyganes could be biogenetically derived from the Aspidosperma alkaloid family, and indeed both groups of alkaloids are found in the same plant species. ${ }^{6}$ A proposed biosynthesis of the schizozyganes from the Aspidosperma alkaloids and further conversion to the isoschizozyganes was initially proposed by Hájíček ${ }^{7}$ and 
this is shown in Scheme 1. An acid catalyzed rearrangement of the aspidosperma skeleton (4) results in the ring-opened schizozygane skeleton $\mathbf{6}$ via intermediate 5. Alternatively, oxidation of 5 would lead to a transient iminium ion intermediate 7. Attack of the indoline nitrogen on the iminium carbon of $\mathbf{7}$ would first produce the aziridinium intermediate $\mathbf{8}$, which might then be opened reductively to give $\mathbf{9}$ and this would be followed by ring closure to provide the isoschizozygane core skeleton $\mathbf{1 0 .}$

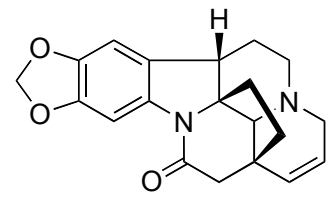

1; schizozygine

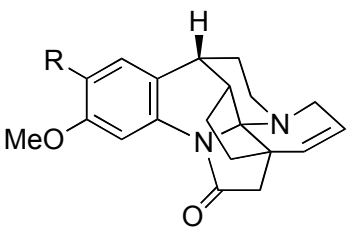

2; $\mathrm{R}=\mathrm{H}$; isoschizogaline

3; $\mathrm{R}=\mathrm{OMe}$; isoschizogamine

\section{Figure 1}
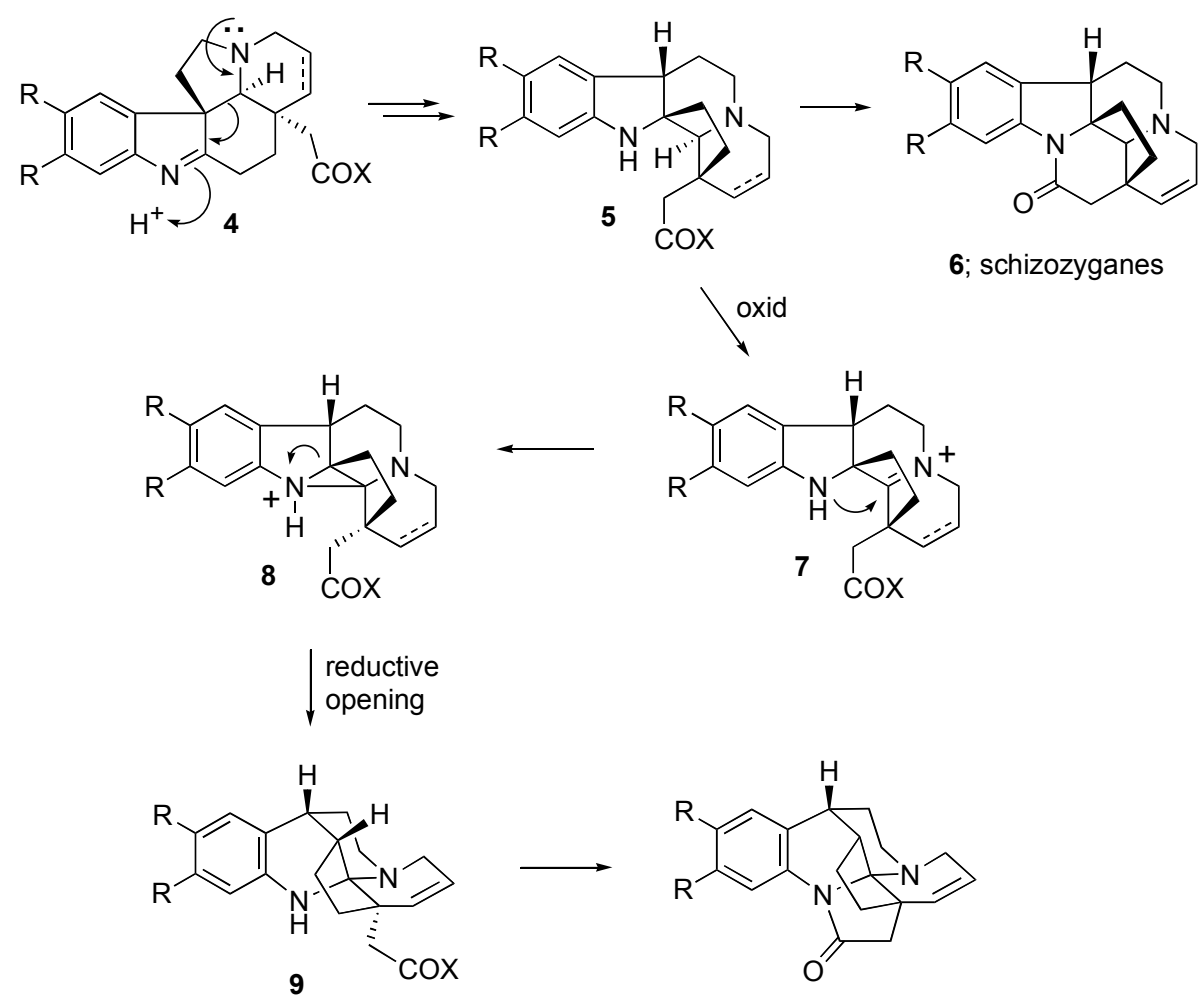

10 ; isoschizozyganes

\section{Scheme 1}

To test this hypothesis, Hájíček and Trojánek carried out a successful biomimetic synthesis of $\left( \pm\right.$ )-strempeliopine based on this proposal. ${ }^{7}$ Rearrangement of pentacycle 11 in AcOH with 
cupric sulfate provided indoline $\mathbf{1 2}$ and a subsequent $N$-formylation gave intermediate $\mathbf{1 3}$ in $40 \%$ yield as shown in Scheme 2. Oxidative cyclization was accomplished by ozonolysis in acidic methanol followed by treatment with $\mathrm{H}_{2} \mathrm{O}_{2}$ to furnish ( \pm )-strempeliopine (14) in $49 \%$ yield.

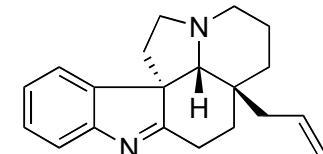

11

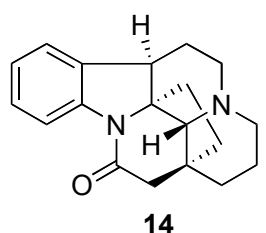

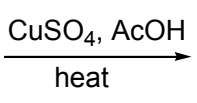

$\frac{\mathrm{O}_{3}, \mathrm{HCl}, \mathrm{MeOH}}{\mathrm{H}_{2} \mathrm{O}_{2}}$
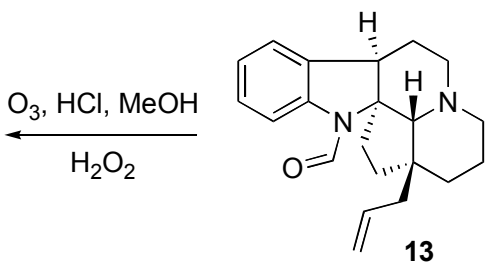

\section{Scheme 2}

Heathcock and Hubbs were the first to describe a concise synthesis of the biogenetically related alkaloid $\left( \pm\right.$ )-isoschizogamine (3). ${ }^{8}$ In their synthesis, the key step to forming the aminal functionality was realized through the attack of an aniline nitrogen onto a transient iminium ion embedded in a 6-6-5 fused ring system ${ }^{9}$ (Scheme 3). Thus, the Michael addition of imine 15 with 16 gave an intermediate which, upon heating, underwent cyclization with concomitant loss of acetone and carbon dioxide providing a mixture of diasteromeric lactams 17. Dehydration of 17 gave 18. The aromatic nitro group and the lactam carbonyl group in $\mathbf{1 8}$ were reduced to $\mathbf{1 9}$, which was then subjected to acidic conditions. The resulting hemiaminal was subsequently oxidized to give ( \pm )-isoschizogamine (3).

More recently, Magomedov presented an alternative strategy to the cyclopenta[b]quinoline core using a formal hetero Diels-Alder reaction to reach a densely functionalized tetrahydroquinoline derivative as an advanced intermediate to the targeted alkaloid. ${ }^{10 \mathrm{a}}$ In a followup approach from his laboratory, an acylamidine intermediate was subjected to acidic conditions, which resulted in an interesting intramolecular cyclization reaction. ${ }^{10 \mathrm{~b}}$ Although his synthetic investigations did not result in a total synthesis of isoschizogamine, Magomedov did point out $10 \mathrm{~b}$ that the synthesis of a key intermediate obtained in his investigations (vide infra) might be useful for an eventual synthesis of this alkaloid using a route previously developed by our group. ${ }^{11}$ 


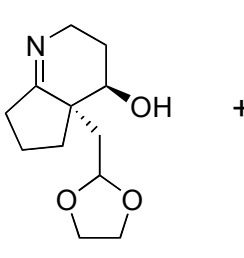

15<smiles>COc1cc(C=C2C(=O)OC(C)(C)OC2=O)c([N+](=O)[O-])cc1OC</smiles>

16<smiles>COc1cc([C@H]2CC(=O)N3CC[C@H](O)C4(C)C3=C2CC[C@@H]4C2OCCO2)c([N+](=O)[O-])cc1OC</smiles>

$\downarrow-\mathrm{H}_{2} \mathrm{O}$<smiles>COc1cc2c(cc1OC)[C@H]1CN3CCN(CC[C@H]21)CC3</smiles>

3; ( \pm )-isoschizogamine

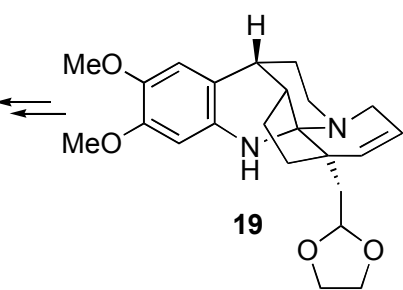<smiles>COc1cc([C@H]2CC(=O)N3CC=C[C@]4(C)CCCC2=C34)c([N+](=O)[O-])cc1OC</smiles>

\section{Scheme 3}

In an earlier report, ${ }^{11}$ we had outlined a new strategy for the synthesis of the isoschizozygane alkaloid core based on the intramolecular 1,4-cycloaddition of a crossconjugated heteroaromatic betaine ${ }^{12}$ across a tethered $\pi$-bond ${ }^{13}$ as illustrated in Scheme 4 . We assumed that the hexacyclic skeleton of isoschizogamine (3) could be formed from a compound of type $\mathbf{2 0}$ by a sequence of enamide protonation, acyl-iminium ion cyclization and lactamization. Enamide $\mathbf{2 0}$ may be generated by extrusion of COS from cycloadduct $\mathbf{2 1}$ followed by reduction of both the nitro and keto groups and a subsequent dehydration.

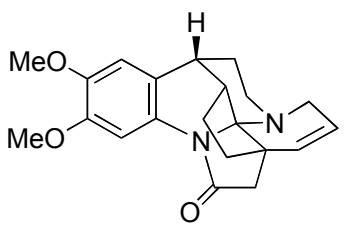

3; (土)-isoschizogamine<smiles></smiles>

22; $\mathrm{Ar}=\mathrm{o}-\mathrm{NO}_{2} \mathrm{C}_{6} \mathrm{H}_{2}(\mathrm{OMe})_{2}$

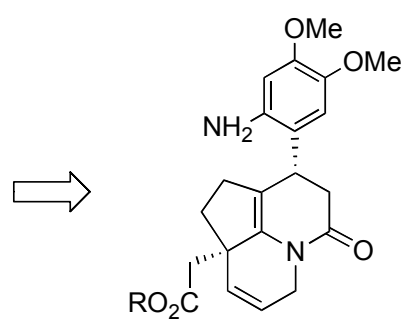

20

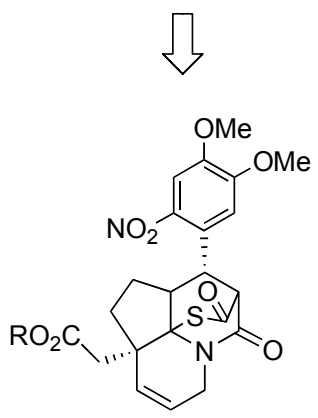

21

\section{Scheme 4}


Although several intermolecular 1,4-dipolar cycloadditions have been described in the literature, ${ }^{14}$ applications of the intramolecular type are still rare but have significant synthetic potential. ${ }^{13}$ In order to test the feasibility of the retrosynthetic strategy outlined in Scheme 4, our initial efforts were focused on model substrates.

\section{Results and Discussion}

The synthesis of 5a-aza-acenaphthylen-5-one $\mathbf{2 6}$ commenced from the easily available thiolactam 23 (Scheme 5). Generation of the bright yellow isolable betaine 24 was accomplished by the reaction of 23 with carbon suboxide 15 at $25{ }^{\circ} \mathrm{C}$ for $5 \mathrm{~h}$. Heating a sample of 24 at $120{ }^{\circ} \mathrm{C}$ for $3 \mathrm{~h}$ in toluene afforded $\mathbf{2 6}$ as a single diastereoisomer in 66\% yield as a pale yellow solid whose formation is easily accounted for by extrusion of $\operatorname{COS}^{16}$ from the originally formed cycloadduct $\mathbf{2 5}$ followed by a hydrogen shift. The preferred stereoselectivity is associated with fewer nonbonded interactions in the transition state for the cycloaddition process. Catalytic reduction of the nitro functionality $\left(\mathrm{H}_{2}, \mathrm{Pd} / \mathrm{C}\right)$ in $\mathbf{2 6}$ to the corresponding amino group was followed by enamide reduction using $\mathrm{LAH}$. The transient enamine $\mathbf{2 7}$ was treated with acid to furnish a 3:2-mixture of diastereomeric aminals $\mathbf{2 8}$ and 29. The formation of the two observed diastereomers can be explained by protonation of the two diastereotopic faces of the double bond in the initially formed enamine 27.8 Treatment of either isolated isomer with acetic acid resulted in an equilibrated 1:6-mixture of $\mathbf{2 8}$ and $\mathbf{2 9}$ with the major diastereomer possessing the correct core skeleton of the isoschizozygane family of alkaloids. 

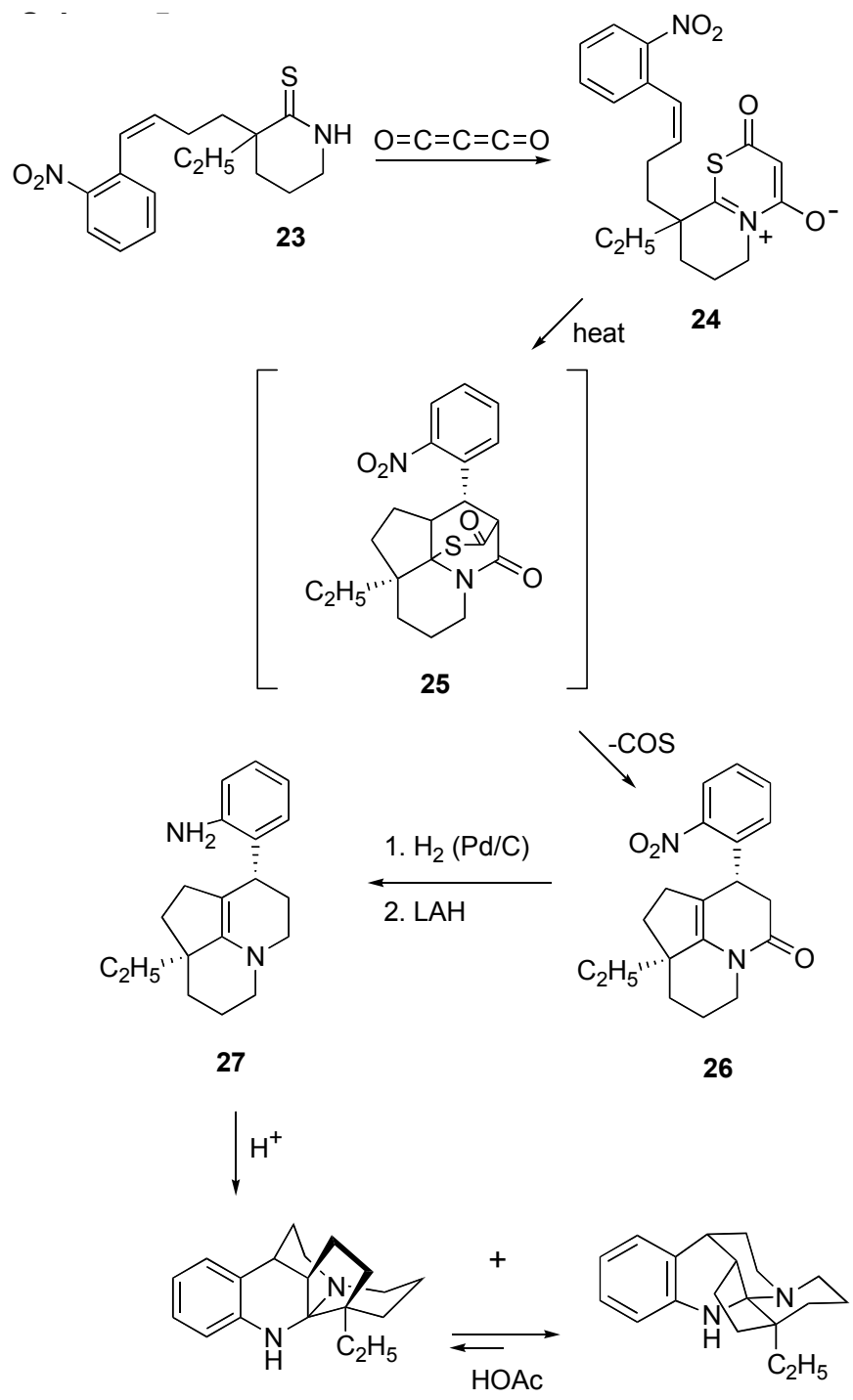

28

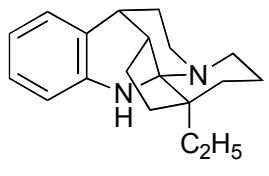

29

\section{Scheme 5}

The above result establishes that the intramolecular 1,4-dipolar cycloaddition of a crossconjugated heteroaromatic betaine intermediate (i.e. 24) can be used as a method to prepare the core skeleton of the isoschizogamine family of alkaloids. Our next task was to synthesize the precursor $\delta$-lactam 30 needed for the generation and cycloaddition of the required betaine intermediate $\mathbf{2 2}$ so as to to eventually furnish compond $\mathbf{3 2}$ as indicated in Scheme 6. 


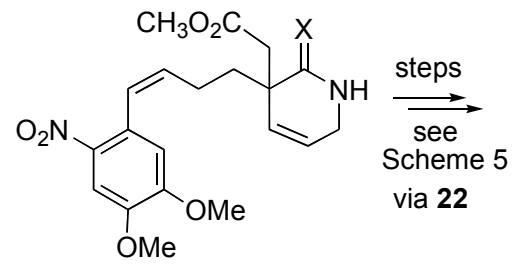

30; $\mathrm{X}=\mathrm{O}$ 31; $X=S$

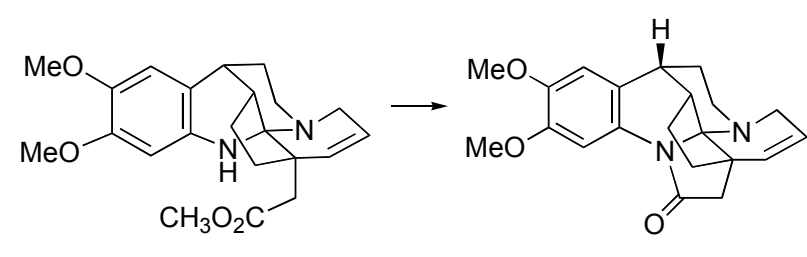

3; ( \pm )-isoschizogamine

\section{Scheme 6}

After inspection of the structural features of $\delta$-lactam 30, we decided to make use of an azaClaisen rearrangement ${ }^{17}$ strategy related to that previously described by Zhou and Magomedov. ${ }^{10 \mathrm{~b}}$ Our efforts to synthesize the required $N$-acetyl aziridine intermediate 39 are outlined in Scheme 7. Toward this goal, alkyne $\mathbf{3 3}$ was readily synthesized by treating the anion derived from methyl diethylphosphonoacetate with but-3-ynyl-4-methylbenzenesulfonate. A subsequent Sonogashira arylation ${ }^{18}$ using 1-bromo-4,5-dimethoxy-2-nitrobenzene with $\mathrm{Cl}_{2} \mathrm{Pd}\left(\mathrm{PPh}_{3}\right)_{2}$ and $\mathrm{CuI}$ as the catalyst provided the expected coupled product 34. Reduction ${ }^{19}$ of the triple bond present in $\mathbf{3 4}$ furnished alkene $\mathbf{3 5}$ as a 9:1-mixture of $Z / E$ isomers. The $\alpha, \beta$ unsaturated ester 39 needed for the aza-Claisen rearrangement was obtained through a HornerWadsworth-Emmons olefination ${ }^{20}$ between phosphonate 35 and the aziridinyl aldehyde $\mathbf{3 6}^{21}$ and was acquired as an inseparable mixture of $E / Z$ isomers $(11: 1)$ about the newly created $\pi$-bond. A number of acidic conditions were attempted for the deprotection of the trityl group in 37, and finally the conditions of $\mathrm{TFA}, \mathrm{Et}_{3} \mathrm{SiH}, 0{ }^{\circ} \mathrm{C}$ were observed to give the best results. ${ }^{22}$ After detritylation the $\mathrm{NH}$-aziridine was obtained primarily as the $Z$-isomer $\mathbf{3 8}$. $\mathrm{N}$-Acetylation of 38 $\left(\mathrm{Ac}_{2} \mathrm{O}, \mathrm{Et}_{3} \mathrm{~N}, \mathrm{CH}_{2} \mathrm{Cl}_{2}\right)$ gave aziridine 39 .

The critical aza-Claisen rearrangement of aziridine 39 under the Somfai conditions ${ }^{17}$ (LHMDS, THF, $-78{ }^{\circ} \mathrm{C}$ to $0{ }^{\circ} \mathrm{C}$ ) did occur, but only in $10 \%$ yield. We had assumed that the release of the aziridine ring-strain would facilitate formation of the seven-membered ring in tetrahydro- $1 H$-azepine 40. Apparently, the low yield is due to a much higher activation energy for this reaction as compared to those reported by Somfai. ${ }^{17}$ The higher activation energy might be due to disruption of conjugation of the $\alpha, \beta$-unsaturated ester in the transition state. We speculated that heating enolate 39a would overcome the energy barrier for the rearrangement, which occurs by a boat-like transition state. Indeed, after 39 was deprotonated (LHMDS, PhMe, $-78{ }^{\circ} \mathrm{C}$ ) and then heated at $80{ }^{\circ} \mathrm{C}$, the starting aziridine had disappeared and the rearranged product $\mathbf{4 0}$ was produced in somewhat better yield (30\%). Further attempts to improve the yield $\mathbf{4 0}$ by varying the solvent, reaction time and temperature were unsuccessful. At this stage of our studies we decided to push ahead and determine whether tetrahydro- $1 H$-azepine $\mathbf{4 0}$ could be converted into the desired $\delta$-lactam precursor $\mathbf{3 0}$ that is ultimately needed for the 1,4cycloaddition step. With this in mind, the NH group of $\mathbf{4 0}$ was protected as the nosyl sulfonate 41. Lactam 41 was then converted to the open chain intermediate 42 by reaction with $\mathrm{NaOMe}$ in 
$\mathrm{MeOH}$. It was necessary to use elevated temperatures (DBU, $\mathrm{CH}_{3} \mathrm{CN}$, reflux) on $\mathbf{4 2}$ to promote the formation of the six-membered lactam 43. Finally, 43 was converted to the desired $\delta$-lactam 30 after nosyl deprotection using $\mathrm{PhSH}, \mathrm{K}_{2} \mathrm{CO}_{3}$ and DMF.<smiles>C#CCCC(C(=O)OC)P(=O)(OCC)OCCCCCCCCCCCCC</smiles><smiles>CCOC(=O)C(CCC#Cc1cc(OC)c(OC)cc1[N+](=O)[O-])C(=O)OC</smiles>

34 $\mathrm{Me}_{2} \mathrm{HSiOSiHMe}_{2}$ $\mathrm{Pd}_{2}(\mathrm{dba})_{3}$<smiles>[R][C@H]1CC1C=C(CCC=Cc1cc(OC)c(OC)cc1[N+](=O)[O-])OC</smiles>

TFA, $\mathrm{Et}_{3} \mathrm{SiH}\left(\begin{array}{l}37 ; \mathrm{R}=\mathrm{Tr} \\ \mathrm{3}\end{array}\right.$ $\mathrm{Ac}_{2} \mathrm{O}, \mathrm{Et}_{3} \mathrm{~N}\left(\begin{array}{l}38 ; \mathrm{R}=\mathrm{H} \\ 39 ; \mathrm{R}=\mathrm{Ac}\end{array}\right.$

\section{Scheme 7}
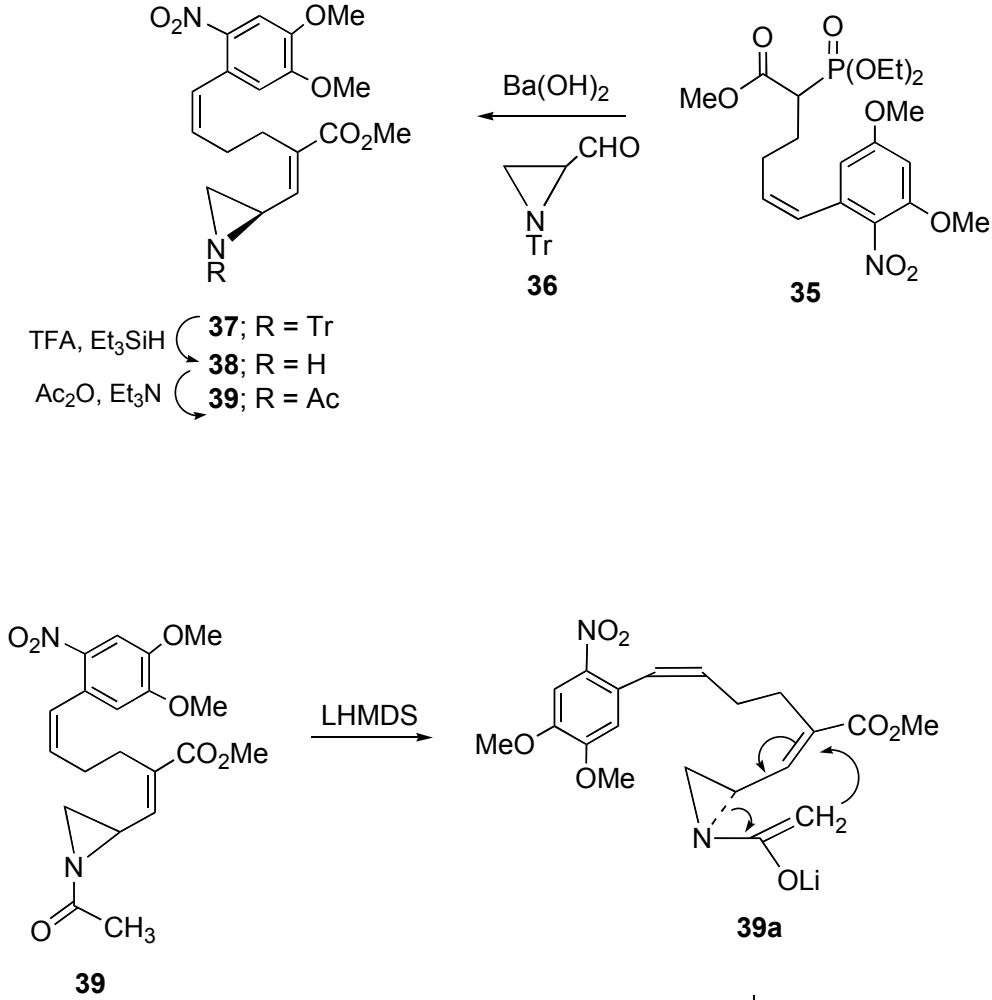

35

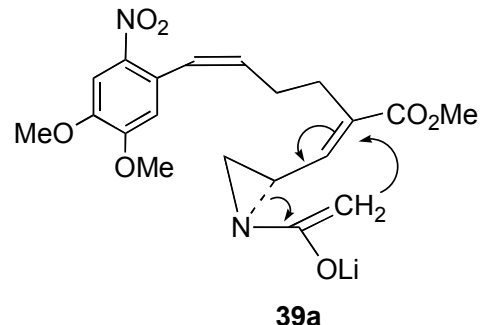

$39 a$

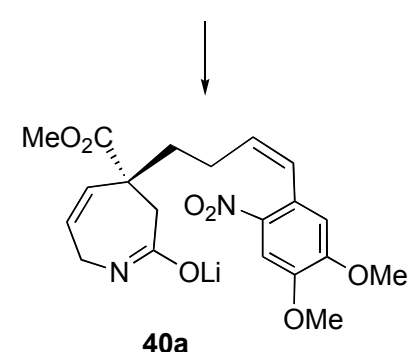

$40 a$

\section{Scheme 8}

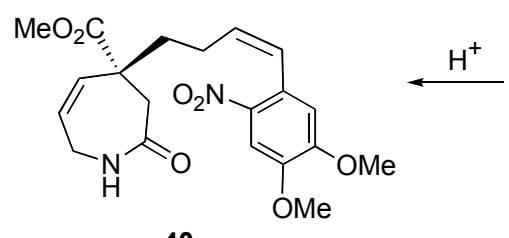

40 

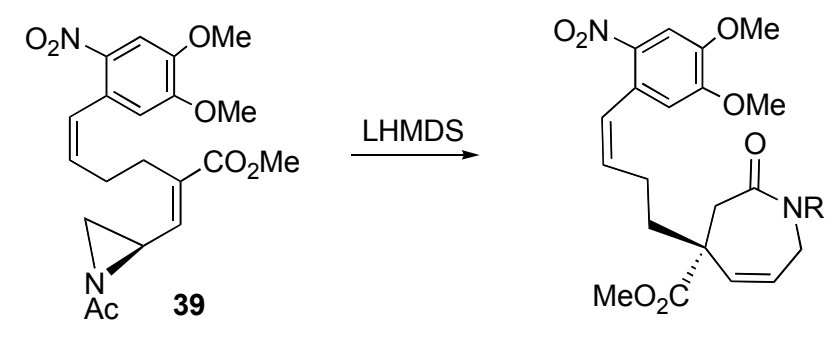

$$
\mathrm{NsCl}\left(\begin{array}{l}
40 ; \mathrm{R}=\mathrm{H} \\
41 ; \mathrm{R}=\mathrm{Ns}
\end{array}\right.
$$

$$
\downarrow \begin{aligned}
& \mathrm{NaOMe} \\
& \mathrm{MeOH}
\end{aligned}
$$<smiles>[R]N1CC=C[C@](CC/C=C\c2cc(OC)c(OC)cc2[N+](=O)[O-])(CCC(C)=O)C1=O</smiles>

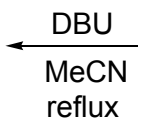<smiles>COC(=O)C[C@](/C=C\CN[N+](=O)[O-])(CC/C=C\c1cc(OC)c(OC)cc1[N+](=O)[O-])CC(C)=O</smiles>

42

$$
\begin{aligned}
& \mathrm{PhSH} \\
& \mathrm{K}_{2} \mathrm{CO}_{3}
\end{aligned}\left(\begin{array}{l}
43 ; \mathrm{R}=\mathrm{Ns} \\
30 ; \mathrm{R}=\mathrm{H}
\end{array}\right.
$$

\section{Scheme 9}

In summary, an efficient approach to the core skeleton of the isoschizozygane family of alkaloids was accomplished by an intramolecular 1,4-dipolar cycloaddition reaction of a crossconjugated heteroaromatic betaine intermediate. Application of this strategy to a total synthesis of $( \pm)$-isoschizogamine is underway and the required substituted piperidin-2-one needed for the eventual 1,4-dipolar cycloaddition step has been prepared using an aza-Claisen rearrangement.

\section{Experimental Section}

3-Ethyl-3-[4-(2-nitrophenyl)-but-3-enyl]-piperidine-2-thione (23). A solution containing $1.5 \mathrm{~g}$ (5.1 mmol) of 3-ethyl-3-[4-(2-nitrophenyl)-but-3-enyl]-piperidin-2-one ${ }^{11}$ and $1.1 \mathrm{~g}$ (2.8 mol) of Lawesson's reagent in $10 \mathrm{~mL}$ of toluene was heated at reflux for $1 \mathrm{~h}$. The resulting mixture was cooled to room temperature, the solvent was removed under reduced pressure and the residue was subjected to silica gel to give $1.4 \mathrm{~g}(87 \%)$ of thioamide 23 as a pale yellow solid: mp 146$148{ }^{\circ} \mathrm{C}$; IR $\left(\mathrm{CH}_{2} \mathrm{Cl}_{2}\right) 3166,3066,2959$, and $1521 \mathrm{~cm}^{-1} ;{ }^{1} \mathrm{H}-\mathrm{NMR}\left(\mathrm{CDCl}_{3}, 400 \mathrm{MHz}\right) \delta 0.86(\mathrm{t}$, $3 \mathrm{H}, J=7.2 \mathrm{~Hz}), 1.50-1.84(\mathrm{~m}, 6 \mathrm{H}), 1.92(\mathrm{sex}, 1 \mathrm{H}, J=6.4 \mathrm{~Hz}), 2.00-2.22(\mathrm{~m}, 3 \mathrm{H}), 3.12-3.28(\mathrm{~m}$, $2 \mathrm{H}), 5.80(\mathrm{dt}, 1 \mathrm{H}, J=11.2$ and $7.2 \mathrm{~Hz}), 6.67(\mathrm{~d}, 1 \mathrm{H}, J=11.2 \mathrm{~Hz}), 7.38(\mathrm{t}, 1 \mathrm{H}, J=8.0 \mathrm{~Hz}), 7.44$ 
$(\mathrm{d}, 1 \mathrm{H}, J=7.6 \mathrm{~Hz}), 7.56(\mathrm{t}, 1 \mathrm{H}, J=7.6 \mathrm{~Hz}), 7.97(\mathrm{~d}, 1 \mathrm{H}, J=8.0 \mathrm{~Hz})$, and $8.80(\mathrm{brs}, 1 \mathrm{H}) ;{ }^{13} \mathrm{C}-$ NMR $\left(\mathrm{CDCl}_{3}, 150 \mathrm{MHz}\right) \delta 8.5,19.4,23.8,27.3,35.3,41.4,45.2,48.6,124.4,125.4,127.7$, 132.1, 132.6, 132.9, 134.1, 148.1, and 210.7; HRMS Calcd for $\mathrm{C}_{17} \mathrm{H}_{22} \mathrm{~N}_{2} \mathrm{O}_{2} \mathrm{~S}$ : 318.1402 . Found: 318.1400 .

\section{9-Ethyl-4-hydroxy-9-[4-(2-nitrophenyl)-but-3-enyl]-2-oxo-6,7,8,9-tetrahydro-2H-pyrido-} $[\mathbf{2 , 1 - b}][\mathbf{1 , 3}]$ thiazin-5-ylium (24). To a solution containing $0.32 \mathrm{~g}(1.0 \mathrm{mmol})$ of thioamide 23 was added carbon suboxide, prepared from $0.15 \mathrm{~g}$ of zinc dust and $0.27 \mathrm{~g}$ of dibromomalonyl dichloride via canular at $-78{ }^{\circ} \mathrm{C}$. The resulting mixture was warmed to room temperature and was stirred at $25{ }^{\circ} \mathrm{C}$ for $5 \mathrm{~h}$. The solvent was removed under reduced pressure and the residue was purified by silica gel chromatography to give $0.28 \mathrm{~g}$ (72\%) of 24 as a bright yellow oil; IR (neat) 2966, 1635, and $1521 \mathrm{~cm}^{-1} ;{ }^{1} \mathrm{H}-\mathrm{NMR}\left(\mathrm{CDCl}_{3}, 400 \mathrm{MHz}\right) \delta 0.92(\mathrm{t}, 3 \mathrm{H}, J=7.2 \mathrm{~Hz}), 1.72-1.82$ $(\mathrm{m}, 3 \mathrm{H}), 1.82-2.00(\mathrm{~m}, 8 \mathrm{H}), 2.04-2.13(\mathrm{~m}, 1 \mathrm{H}), 4.05(\mathrm{dt}, 1 \mathrm{H}, J=15.6$ and $6.4 \mathrm{~Hz}), 4.17(\mathrm{dt}, 1 \mathrm{H}, J$ $=15.6$ and $6.4 \mathrm{~Hz}), 5.72(\mathrm{dt}, 1 \mathrm{H}, J=11.2$ and $6.8 \mathrm{~Hz}), 7.23(\mathrm{~d}, 1 \mathrm{H}, J=7.6 \mathrm{~Hz}), 7.47(\mathrm{td}, 1 \mathrm{H}, J=$ 7.6 and $1.2 \mathrm{~Hz}), 7.59(\mathrm{td}, 1 \mathrm{H}, J=7.6$ and $1.2 \mathrm{~Hz})$, and $8.01(\mathrm{dd}, 1 \mathrm{H}, J=7.6$ and $1.2 \mathrm{~Hz}) ;{ }^{13} \mathrm{C}-$ NMR $\left(\mathrm{CDCl}_{3}, 100 \mathrm{MHz}\right) \delta 8.5,19.0,23.3,28.2,36.8,42.6,47.9,49.6,88.0,124.7,127.6,128.6$, 130.9, 131.3, 131.8, 133.1, 148.1, 161.5, 166.4, and 194.2; HRMS Calcd for $\mathrm{C}_{20} \mathrm{H}_{22} \mathrm{~N}_{2} \mathrm{O}_{4} \mathrm{~S}$ : 386.1300. Found: 386.1297.

8a-Ethyl-3-(2-nitrophenyl)-1,2,3,4,6,7,8,8a-octahydro-5a-aza-acenaphthylen-5-one (26). A mixture containing $0.28 \mathrm{~g}(0.72 \mathrm{mmol})$ of dipole 24 in $15 \mathrm{~mL}$ of toluene in a sealed tube was placed in a preheated oil bath at $120{ }^{\circ} \mathrm{C}$ for $3 \mathrm{~h}$. The mixture was cooled to room temperature and the solvent was removed under reduced pressure. The residue was purified by silica gel chromatography to give $0.18 \mathrm{~g}(66 \%)$ of 26 as a pale yellow solid; mp 134-136 ${ }^{\circ} \mathrm{C}$; IR (neat) 2942, 1683, and $1321 \mathrm{~cm}^{-1} ;{ }^{1} \mathrm{H}-\mathrm{NMR}\left(\mathrm{CDCl}_{3}, 400 \mathrm{MHz}\right) \delta 0.91(\mathrm{t}, 3 \mathrm{H}, J=7.2 \mathrm{~Hz}), 1.19-1.30$ $(\mathrm{m}, 1 \mathrm{H}), 1.44-1.65(\mathrm{~m}, 3 \mathrm{H}), 1.69-1.82(\mathrm{~m}, 3 \mathrm{H}), 1.91-2.02(\mathrm{~m}, 2 \mathrm{H}), 2.04-2.15(\mathrm{~m}, 1 \mathrm{H}), 2.67(\mathrm{t}$, $1 \mathrm{H}, J=14.8 \mathrm{~Hz}), 2.95(\mathrm{dd}, 1 \mathrm{H}, J=14.8$ and $6.0 \mathrm{~Hz}), 3.07(\mathrm{dt}, 1 \mathrm{H}, J=12.8$ and $8.0 \mathrm{~Hz}), 3.96(\mathrm{dt}$, $1 \mathrm{H}, J=12.8$ and $4.4 \mathrm{~Hz}), 4.34(\mathrm{dd}, 1 \mathrm{H}, J=14.8$ and $6.0 \mathrm{~Hz}), 7.26-7.41(\mathrm{~m}, 2 \mathrm{H}), 7.59(\mathrm{td}, 1 \mathrm{H}, J$ $=7.6$ and $1.2 \mathrm{~Hz})$, and $7.79(\mathrm{dd}, 1 \mathrm{H}, J=7.6$ and $1.2 \mathrm{~Hz}) ;{ }^{13} \mathrm{C}-\mathrm{NMR}\left(\mathrm{CDCl}_{3}, 100 \mathrm{MHz}\right) \delta 9.1$, $19.3,27.5,28.3,31.8,34.7,36.0,40.9,41.0,45.8,114.5,124.3,127.5,129.9,132.8,136.8$, 143.4, 150.1, and 169.6; Anal. Calcd for $\mathrm{C}_{19} \mathrm{H}_{22} \mathrm{~N}_{2} \mathrm{O}_{3}$ : C, 69.92; H, 6.79; N, 8.58. Found: C, 69.84; H, 6.80; N, 8.45.

Preparation of Aminals 28 and 29. A mixture containing $0.027 \mathrm{~g}$ (0.08 mmol) of lactam 26 and $0.03 \mathrm{~g}$ of $\mathrm{Pd} / \mathrm{C}$ was stirred under a hydrogen atmosphere $(4 \mathrm{~atm})$ for $15 \mathrm{~h}$. The reaction mixture was filtered through a celite pad and the filtrate was concentrated under reduced pressure. The residue was taken up in $5 \mathrm{~mL}$ of THF and this solution was treated with $0.065 \mathrm{~g}(1.7 \mathrm{mmol})$ of $\mathrm{LAH}$ at $0{ }^{\circ} \mathrm{C}$. The mixture was heated at reflux for $20 \mathrm{~h}$ and was cooled to room temperature. To this mixture was added $65 \mathrm{~mL}$ of water, $65 \mathrm{~mL}$ of $15 \%$ of $\mathrm{NaOH}$ and $195 \mathrm{~mL}$ of water followed by the addition of $1 \mathrm{~g}$ of anhydrous $\mathrm{Na}_{2} \mathrm{SO}_{4}$ and the mixture was filtered. The solution was concentrated under reduced pressure and the resulting residue was purified by silica gel chromatography to give $0.01 \mathrm{~g}(48 \%)$ of the undesired aminal diasteromer $\mathbf{2 8}$ as a pale yellow oil; IR (neat) 3433, 2920, and $1321 \mathrm{~cm}^{-1} ;{ }^{1} \mathrm{H}-\mathrm{NMR}\left(\mathrm{CDCl}_{3}, 400 \mathrm{MHz}\right) \delta 0.78(\mathrm{t}, 3 \mathrm{H}, J=7.6 \mathrm{~Hz})$, 
$1.10(\mathrm{td}, 1 \mathrm{H}, J=13.6$ and $4.8 \mathrm{~Hz}), 1.24-1.41(\mathrm{~m}, 3 \mathrm{H}), 1.44-1.52(\mathrm{~m}, 1 \mathrm{H}), 1.56-1.62(\mathrm{~m}, 2 \mathrm{H})$, $1.64-1.73(\mathrm{~m}, 1 \mathrm{H}), 1.80$ (qt, $1 \mathrm{H}, J=13.2$ and $4.8 \mathrm{~Hz}), 1.97-2.14(\mathrm{~m}, 2 \mathrm{H}), 2.24-2.52(\mathrm{~m}, 6 \mathrm{H})$, $2.93(\mathrm{~d}, 1 \mathrm{H}, J=3.2 \mathrm{~Hz}), 4.51(\mathrm{brs}, 1 \mathrm{H}), 6.52(\mathrm{~d}, 1 \mathrm{H}, J=8.0 \mathrm{~Hz}), 6.56(\mathrm{td}, 1 \mathrm{H}, J=7.2$ and 1.2 $\mathrm{Hz}), 6.91(\mathrm{dd}, 1 \mathrm{H}, J=7.6$ and $1.2 \mathrm{~Hz})$, and $6.97(\mathrm{td}, 1 \mathrm{H}, J=7.6$ and $1.6 \mathrm{~Hz}) ;{ }^{13} \mathrm{C}-\mathrm{NMR}\left(\mathrm{CDCl}_{3}\right.$, $100 \mathrm{MHz}) \delta 8.3,21.2,21.8,27.7,28.0,28.8,29.4,35.4,41.2,46.3,46.6,48.3,75.3,112.1$, 116.1, 126.9, 127.2, 128.6, and 146.9; HRMS Calcd for $\mathrm{C}_{19} \mathrm{H}_{26} \mathrm{~N}_{2}: 282.2096$. Found: 282.2091.

The second fraction from the above chromatographic separation contained $0.008 \mathrm{~g}(35 \%)$ of the desired aminal diasteromer 29 as a white solid; mp 122-124 ${ }^{\circ} \mathrm{C}$; IR (neat) 3420, 2939, and 1311 $\mathrm{cm}^{-1}$; ${ }^{1} \mathrm{H}-\mathrm{NMR}\left(\mathrm{CDCl}_{3}, 400 \mathrm{MHz}\right) \delta 0.87(\mathrm{t}, 3 \mathrm{H}, J=7.6 \mathrm{~Hz}), 1.02-1.15(\mathrm{~m}, 1 \mathrm{H}), 1.18-1.70(\mathrm{~m}$, $8 \mathrm{H}), 1.74-1.80(\mathrm{~m}, 1 \mathrm{H}), 1.81-1.88(\mathrm{~m}, 1 \mathrm{H}), 2.13(\mathrm{tt}, 1 \mathrm{H}, J=13.2$ and $4.0 \mathrm{~Hz}), 2.41(\mathrm{dd}, 1 \mathrm{H}, J=$ 14.4 and $3.2 \mathrm{~Hz}), 2.68-2.74(\mathrm{~m}, 1 \mathrm{H}), 2.78-2.87(\mathrm{~m}, 1 \mathrm{H}), 2.98(\mathrm{dt}, 1 \mathrm{H}, J=12.0$ and $3.6 \mathrm{~Hz}), 3.00-$ $3.04(\mathrm{~m}, 1 \mathrm{H}), 3.13(\mathrm{dt}, 1 \mathrm{H}, J=14.0$ and $3.6 \mathrm{~Hz}), 4.14(\mathrm{brs}, 1 \mathrm{H}), 6.45(\mathrm{~d}, 1 \mathrm{H}, J=8.0 \mathrm{~Hz}), 6.60$ $(\mathrm{td}, 1 \mathrm{H}, J=8.0$ and $0.8 \mathrm{~Hz}), 6.93(\mathrm{dd}, 1 \mathrm{H}, J=8.0$ and $1.2 \mathrm{~Hz})$, and $7.01(\mathrm{td}, 1 \mathrm{H}, J=8.0$ and 1.2 $\mathrm{Hz}) ;{ }^{13} \mathrm{C}-\mathrm{NMR}\left(\mathrm{CDCl}_{3}, 100 \mathrm{MHz}\right) \delta 9.3,22.0,22.6,23.5,28.0,30.4,33.8,34.7,45.1,45.9,48.9$, 76.0, 111.9, 116.8, 122.4, 127.4, 129.0, and 144.7; HRMS Calcd for $\mathrm{C}_{19} \mathrm{H}_{26} \mathrm{~N}_{2}: 282.2096$. Found: 282.2094 .

A $0.02 \mathrm{~g}$ sample containing either aminal $\mathbf{2 8}$ or $\mathbf{2 9}$ was dissolved in $1 \mathrm{~mL}$ of acetic acid at room temperature. The solution was stirred for $2 \mathrm{~h}$ at $\mathrm{rt}$ and was then poured into $10 \mathrm{~mL}$ of a saturated sodium bicarbonate solution and extracted with $\mathrm{CH}_{2} \mathrm{Cl}_{2}$. The solution was dried over $\mathrm{MgSO}_{4}$ and the solvent was removed under reduced pressure. The residue was analyzed by ${ }^{1} \mathrm{H}-\mathrm{NMR}$ spectroscopy $\left(\mathrm{CDCl}_{3}, 400 \mathrm{MHz}\right)$ which indicated a 1:6-mixture of aminals 28 (minor) and 29 (major).

Methyl 2-(diethoxyphosphoryl)hex-5-ynoate (33). To a solution containing $2.0 \mathrm{~mL}$ (11 mmol) of methyl diethylphosphonoacetate in $45 \mathrm{~mL}$ of THF at $0{ }^{\circ} \mathrm{C}$ was added $22 \mathrm{~mL}(0.5 \mathrm{M}, 11 \mathrm{mmol})$ of a KHMDS solution in toluene. After stirring at $0{ }^{\circ} \mathrm{C}$ for $30 \mathrm{~min}$, a solution containing $1.65 \mathrm{~g}$ (7.4 mmol) of but-3-ynyl 4-methylbenzenesulfonate in $15 \mathrm{~mL}$ of THF was added. The mixture was heated to $50{ }^{\circ} \mathrm{C}$ and stirred for an additional $15 \mathrm{~h}$. After cooling to rt, the reaction mixture was quenched by the addition of $\mathrm{H}_{2} \mathrm{O}(100 \mathrm{~mL})$ and extracted with $\mathrm{Et}_{2} \mathrm{O}$. The combined organic extracts were dried over anhydrous $\mathrm{MgSO}_{4}$, filtered, and concentrated under reduced pressure. Purification of the residue by flash column silica gel chromatography gave $0.6 \mathrm{~g}(31 \%)$ of the titled compound as a clear oil: IR (neat) 3473, 3288, 3230, 2984, 2953, 1737, 1438 1252, and $1158 \mathrm{~cm}^{-1} ;{ }^{1} \mathrm{H}-\mathrm{NMR}\left(\mathrm{CDCl}_{3}, 400 \mathrm{MHz}\right) \delta 1.31(\mathrm{ddd}, 6 \mathrm{H}, J=7.1,7.1$ and $2.7 \mathrm{~Hz}), 1.98(\mathrm{t}, 1 \mathrm{H}, J$ $=2.7 \mathrm{~Hz}), 2.00-2.09(\mathrm{~m}, 1 \mathrm{H}), 2.13-2.25(\mathrm{~m}, 2 \mathrm{H}), 2.30-2.38(\mathrm{~m}, 1 \mathrm{H}), 3.20(\mathrm{ddd}, 1 \mathrm{H}, J=23.5$, 10.2, and 4.3 Hz), $3.75(\mathrm{~s}, 3 \mathrm{H})$, and 4.09-4.18 (m, 4H); ${ }^{13} \mathrm{C}-\mathrm{NMR}\left(\mathrm{CDCl}_{3}, 100 \mathrm{MHz}\right) \delta 16.5(\mathrm{~d}, J$ $=3.0 \mathrm{~Hz}), 16.5(\mathrm{~d}, J=3.0 \mathrm{~Hz}), 17.4(\mathrm{~d}, J=15.6 \mathrm{~Hz}), 25.9(\mathrm{~d}, J=4.5 \mathrm{~Hz}), 44.2(\mathrm{~d}, J=30.9 \mathrm{~Hz})$, $52.7,63.0(\mathrm{~d}, J=6.7 \mathrm{~Hz}), 63.1(\mathrm{~d}, J=6.7 \mathrm{~Hz}), 70.0,82.3$, and $169.4(\mathrm{~d}, J=5.3 \mathrm{~Hz})$.

Methyl 2-(3-(4-(4,5-dimethoxy-2-nitrophenyl)but-3-enyl)-2-oxo-1,2,3,6-tetrahydropyri-din3-yl)acetate (30). ${ }^{24}$ To a solution containing $0.54 \mathrm{~g}(2.0 \mathrm{mmol})$ of the above alkyne and $0.64 \mathrm{~g}$ $(2.5 \mathrm{mmol})$ of 1-bromo-4,5-dimethoxy-2-nitrobenzene in diisopropylamine $(8.5 \mathrm{~mL})$ and $\mathrm{THF}$ $(17 \mathrm{~mL})$ at $\mathrm{rt}$ was added $36 \mathrm{mg}(0.051 \mathrm{mmol})$ of dichlorobis(triphenylphosphine) palladium (II) 
and $19 \mathrm{mg}(0.10 \mathrm{mmol})$ of CuI. The resulting mixture was stirred at $\mathrm{rt}$ for $15 \mathrm{~h}$ then filtered through a Celite pad eluting with EtOAc $(50 \mathrm{~mL})$. The filtrate was concentrated under reduced pressure and the residue was purified by flash column silica gel chromatography to provide 0.57 g (62\%) of methyl 2-(diethoxyphosphoryl)-6-(4,5-dimethoxy-2-nitrophenyl)-hex-5-ynoate (34) as a red oil: IR (neat) 3463, 2982, 2942, 1735, 1573, 1521, 1284, 1215, and $1020 \mathrm{~cm}^{-1} ;{ }^{1} \mathrm{H}-\mathrm{NMR}$ $\left(\mathrm{CDCl}_{3}, 400 \mathrm{MHz}\right) \delta 1.34(\mathrm{ddd}, 6 \mathrm{H}, J=7.0,7.0$ and $4.3 \mathrm{~Hz}), 2.14-2.25(\mathrm{~m}, 1 \mathrm{H}), 2.27-2.39(\mathrm{~m}$, $1 \mathrm{H}), 2.51-2.59(\mathrm{~m}, 1 \mathrm{H}), 2.63-2.71(\mathrm{~m}, 1 \mathrm{H}), 3.36(\mathrm{ddd}, 1 \mathrm{H}, J=23.5,10.6$, and $4.3 \mathrm{~Hz}), 3.76(\mathrm{~s}$, $3 \mathrm{H}), 3.95(\mathrm{~s}, 3 \mathrm{H}), 3.96(\mathrm{~s}, 3 \mathrm{H}), 4.10-4.22(\mathrm{~m}, 4 \mathrm{H}), 6.96(\mathrm{~s}, 1 \mathrm{H}), 7.61(\mathrm{~s}, 1 \mathrm{H}) ;{ }^{13} \mathrm{C}-\mathrm{NMR}\left(\mathrm{CDCl}_{3}\right.$, $100 \mathrm{MHz}) \delta 16.5(\mathrm{~d}, J=3.0 \mathrm{~Hz}), 16.6(\mathrm{~d}, J=3.0 \mathrm{~Hz}), 18.9(\mathrm{~d}, J=15.6 \mathrm{~Hz}), 25.9(\mathrm{~d}, J=4.5 \mathrm{~Hz})$, $44.3(\mathrm{~d}, J=30.2 \mathrm{~Hz}), 52.8,56.6,56.7,63.1(\mathrm{~d}, J=7.5 \mathrm{~Hz}), 63.1(\mathrm{~d}, J=7.5 \mathrm{~Hz}), 78.4,95.4$, $107.6,113.2,115.7,142.9,148.6,152.8$, and $169.5(\mathrm{~d}, J=5.3 \mathrm{~Hz})$.

To a solution of $1.2 \mathrm{~g}(2.7 \mathrm{mmol})$ of the above alkyne, $0.1 \mathrm{~g}(0.11 \mathrm{mmol})$ of $\operatorname{Pd}_{2}(\mathrm{dba})_{3}$, and 66 $\mathrm{mg}(0.22 \mathrm{mmol})$ of $(o$-tolyl $) \mathrm{P}_{3}$ in benzene $(27 \mathrm{~mL})$ at $\mathrm{rt}$ was added $0.15 \mathrm{~mL}(2.7 \mathrm{mmol})$ of $\mathrm{AcOH}$, and $0.48 \mathrm{~mL}(2.7 \mathrm{mmol})$ of 1,1,3,3-tetramethyldisiloxane. The reaction mixture was stirred at $\mathrm{rt}$ for $15 \mathrm{~h}$ then poured into $\mathrm{H}_{2} \mathrm{O}$ and extracted with EtOAc. The combined organic extracts were dried over anhydrous $\mathrm{MgSO}_{4}$, filtered, and concentrated under reduced pressure. Purification of the residue by flash column silica gel chromatography resulted in $1.06 \mathrm{~g}(88 \%)$ a 9:1 inseparable mixture of the $Z$ :E-isomers of methyl 2-(diethoxyphosphoryl)-6-(4,5-dimethoxy2-nitrophenyl)hex-5-enoate (35) as a dark oil.

A solution of $0.41 \mathrm{~g}(2.4 \mathrm{mmol})$ of $\mathrm{Ba}(\mathrm{OH})_{2}$ and $1.06 \mathrm{~g}(2.4 \mathrm{mmol})$ of the above alkene in THF $(21 \mathrm{~mL})$ and $\mathrm{H}_{2} \mathrm{O}(2.4 \mathrm{~mL})$ was stirred at $\mathrm{rt}$ for $30 \mathrm{~min}$. To the reaction mixture was added $0.75 \mathrm{~g}$ (2.4 mmol) of $(S)$-1-tritylaziridine-2-carbaldehyde (36) and the mixture was stirred for an additional $15 \mathrm{~h}$. The solution was then poured into $\mathrm{CH}_{2} \mathrm{Cl}_{2}$ and washed with saturated aqueous $\mathrm{NaHCO}_{3}$. The combined organic extracts were dried over anhydrous $\mathrm{Na}_{2} \mathrm{SO}_{4}$, filtered, and concentrated under reduced pressure. Purification of the residue by flash column silica gel chromatography resulted in $1.1 \mathrm{~g}(76 \%)$ of methyl 6-(4,5-dimethoxy-2-nitrophenyl)-2-(( $R)-1$ tritylaziridin-2-yl)methyl-ene)hex-5-enoate (37) as a yellow oil.

To a solution containing $1.1 \mathrm{~g}(1.8 \mathrm{mmol})$ of the above aziridine in $\mathrm{CH}_{2} \mathrm{Cl}_{2}(75 \mathrm{~mL})$ at $0{ }^{\circ} \mathrm{C}$ was added $1.2 \mathrm{~mL}(7.2 \mathrm{mmol})$ of triethylsilane and then $0.54 \mathrm{~mL}(7.2 \mathrm{mmol})$ of TFA was added dropwise over $5 \mathrm{~min}$. After stirring the bright yellow solution at $0{ }^{\circ} \mathrm{C}$ for an additional $25 \mathrm{~min}$, $1.9 \mathrm{~mL}(10.9 \mathrm{mmol})$ of diisopropylethylamine was added. After stirring for $30 \mathrm{~min}$, the reaction was quenched by the addition of $\mathrm{H}_{2} \mathrm{O}$ and extracted with $\mathrm{CH}_{2} \mathrm{Cl}_{2}$. The combined organic extracts were dried over anhydrous $\mathrm{Na}_{2} \mathrm{SO}_{4}$, filtered, and concentrated under reduced pressure. Purification of the residue by flash column silica gel chromatography resulted in $0.46 \mathrm{~g}(71 \%)$ of methyl 2-((R)-aziridin-2-ylmethylene)-6-(4,5-dimethoxy-2-nitrophenyl)hex-5-enoate (38) as a light yellow oil.

To $0.47 \mathrm{~g}(1.28 \mathrm{mmol})$ of the above aziridine in $\mathrm{CH}_{2} \mathrm{Cl}_{2}(13 \mathrm{~mL})$ at $0{ }^{\circ} \mathrm{C}$ was added $0.36 \mathrm{~mL}(2.6$ $\mathrm{mmol})$ of $\mathrm{NEt}_{3}$ followed by $16 \mathrm{mg}(0.13 \mathrm{mmol})$ of DMAP. After the addition of $0.13 \mathrm{~mL}(1.4$ $\mathrm{mmol}$ ) of $\mathrm{Ac}_{2} \mathrm{O}$, the reaction mixture was allowed to stir for $20 \mathrm{~min}$. The solution was quenched by the addition of $\mathrm{H}_{2} \mathrm{O}$ and extracted with $\mathrm{CH}_{2} \mathrm{Cl}_{2}$. The combined organic extracts were dried 
over anhydrous $\mathrm{Na}_{2} \mathrm{SO}_{4}$, filtered, and concentrated under reduced pressure. Purification of the residue by flash column silica gel chromatography resulted in $0.45 \mathrm{~g}(86 \%)$ of methyl 2-(( $R)-1$ acetylaziridin-2-yl)methylene)-6-(4,5-dimethoxy-2-nitrophenyl)hex-5-enoate (39) as a light yellow.

A solution of $0.23 \mathrm{~g}(0.56 \mathrm{mmol})$ of the above aziridine in toluene $(10 \mathrm{~mL})$ was cooled to -78 ${ }^{\circ} \mathrm{C}$. A solution of $0.95 \mathrm{~mL}(1.0 \mathrm{M}$ in hexanes, $0.95 \mathrm{mmol})$ of LiHMDS was added dropwise over $5 \mathrm{~min}$. After stirring the light yellow solution at $-78{ }^{\circ} \mathrm{C}$ for $20 \mathrm{~min}$, the reaction mixture was placed in a preheated $\left(80^{\circ} \mathrm{C}\right)$ oil bath and heated at this temperature for an additional 20 min. The mixture was then cooled to $\mathrm{rt}$ and quenched by the addition of saturated aqueous $\mathrm{NH}_{4} \mathrm{Cl}$ and extracted with $\mathrm{Et}_{2} \mathrm{O}$. The combined organic extracts were dried over anhydrous $\mathrm{MgSO}_{4}$, filtered, and concentrated under reduced pressure. Purification of the residue by flash column silica gel chromatography resulted in $59 \mathrm{mg}$ (30\%) of methyl 4-(4-(4,5-dimethoxy-2-nitrophenyl)but-3enyl)-2-oxo-2,3,4,7-tetrahydro-1 $H$-azepine-4-carboxylate (40) as a light yellow oil.

To a solution of $56 \mathrm{mg}(0.14 \mathrm{mmol})$ of the above lactam in THF $(2 \mathrm{~mL})$ at $-78{ }^{\circ} \mathrm{C}$ was added $0.21 \mathrm{~mL}(1.0 \mathrm{M}$ solution in THF, $0.21 \mathrm{mmol})$ of NaHMDS. After stirring for $30 \mathrm{~min}$ at $-78{ }^{\circ} \mathrm{C}$, a solution of $46 \mathrm{mg}(0.21 \mathrm{mmol})$ of $\mathrm{NsCl}$ in $1 \mathrm{~mL}$ THF was added and the dark purple reaction mixture was stirred an additional $2 \mathrm{~h}$. The reaction was diluted with $\mathrm{Et}_{2} \mathrm{O}$ and quenched cold with $\mathrm{H}_{2} \mathrm{O}$. After warming to rt, the mixture was poured into $\mathrm{H}_{2} \mathrm{O}$ and extracted with $\mathrm{Et}_{2} \mathrm{O}$. The combined organic extracts were dried over anhydrous $\mathrm{MgSO}_{4}$, filtered, and concentrated under reduced pressure. Purification of the residue by flash column silica gel chromatography gave 34 mg (41\%) of methyl 4-(4-(4,5-dimethoxy-2-nitrophenyl)but-3-enyl)-1-(4-nitrophenylsulfonyl)-2oxo-2,3,4,7-tetrahydro- $1 H$-azepine-4-carboxylate (41) as a yellow oil.

To a solution of $48 \mathrm{mg}(0.082 \mathrm{mmol})$ of the above lactam in THF $(1.5 \mathrm{~mL})$ and $\mathrm{MeOH}(1.5 \mathrm{~mL})$ at $\mathrm{rt}$ was added $9.0 \mathrm{mg}(0.16 \mathrm{mmol})$ of $\mathrm{NaOMe}$ in one portion. After stirring at $\mathrm{rt}$ for $30 \mathrm{~min}$, the reaction was diluted with $\mathrm{Et}_{2} \mathrm{O}$, quenched by the addition of saturated aqueous $\mathrm{NH}_{4} \mathrm{Cl}$, and extracted with $\mathrm{Et}_{2} \mathrm{O}$. The combined organic extracts were dried over anhydrous $\mathrm{MgSO}_{4}$, filtered, and concentrated under reduced pressure provided the diester $\mathbf{4 2}$ which was used in the next step without purification. To the above ring-opened diester in $\mathrm{CH}_{3} \mathrm{CN}(3 \mathrm{~mL})$ at $\mathrm{rt}$ was added $18 \mu \mathrm{L}$ $(0.12 \mathrm{mmol})$ of DBU. The reaction mixture was heated to reflux for $1 \mathrm{~h}$. After cooling to $\mathrm{rt}$, the reaction mixture was quenched by the addition of saturated aqueous $\mathrm{NH}_{4} \mathrm{Cl}$ and extracted with $\mathrm{Et}_{2} \mathrm{O}$. The combined organic extracts were dried over anhydrous $\mathrm{MgSO}_{4}$, filtered, and concentrated under reduced pressure. Purification of the residue by flash column silica gel chromatography gave $37 \mathrm{mg}$ (77\%) of methyl 2-(3-(4-(4,5-dimethoxy-2-nitrophenyl)but-3-enyl)1-(4-nitrophenylsulfonyl)-2-oxo-1,2,3,6-tetrahydropyridin-3-yl)acetate (43) as a yellow oil.

To a solution of $27 \mathrm{mg}(0.046 \mathrm{mmol})$ of the above lactam and $19 \mathrm{mg}(0.95 \mathrm{mmol}) \mathrm{K}_{2} \mathrm{CO}_{3}$ in DMF $(1 \mathrm{~mL})$ at $\mathrm{rt}$ was added $6.0 \mu \mathrm{L}(0.055 \mathrm{mmol})$ of $\mathrm{PhSH}$. After stirring for $1 \mathrm{~h}$ at $\mathrm{rt}$, the reaction was diluted with $\mathrm{Et}_{2} \mathrm{O}$, quenched by the addition of saturated aqueous $\mathrm{NaHCO}_{3}$, and extracted with $\mathrm{Et}_{2} \mathrm{O}$ and EtOAc. The combined organic extracts were dried over anhydrous $\mathrm{MgSO}_{4}$, filtered, and concentrated under reduced pressure. Purification of the residue by preparative TLC on silica gel gave $13 \mathrm{mg}$ (71\%) of methyl 2-(3-(4-(4,5-dimethoxy-2- 
nitrophenyl)but-3-enyl)-2-oxo-1,2,3,6-tetrahydropyridin-3-yl)acetate (30) as an inseparable 2:1 mixture of $Z: E$ alkene isomers.

\section{Acknowledgements}

We appreciate the financial support provided by the National Science Foundation (Grant CHE0742663).

\section{References}

1. Saxton, J. E. In Indoles, Part Four, The Monoterpenoid Indole Alkaloids; Saxton, J. E., Ed.; John Wiley: New York, 1984; Chapter IX, pp 437-486.

2. Renner, U.; Kernweisz, P. Experientia 1963, 19, 244.

3. Hájicek, J.; Taimr, J.; Budesinsky, M. Tetrahedron Lett. 1998, 39, 505.

4. Renner, U.; Fritz, H. Helv. Chim. Acta 1965, 48, 308.

5. Renner, U. Lloydia 1964, 27, 406.

6. Kariba, R. M.; Houghton, P. J.; Yenesew, A. J. Nat. Prod. 2002, 65, 566.

7. (a) Hájíček, J.; Trojánek, J. Tetrahedron Lett. 1981, 22, 2927. (b) Hájíček, J.; Trojánek, J. Tetrahedron Lett. 1982, 23, 365. (c) Hájíček, J.; Trojánek, J. Collect. Czech. Chem. Commun. 1986, 51, 1731.

8. Hubbs, J. L.; Heathcock, C. H. Org. Lett. 1999, 1, 1315.

9. Kompis, I.; Hesse, M.; Schmid, H. Lloydia 1971, 34, 269.

10. (a) Magomedov, N. A. Org. Lett. 2003, 5, 2509. (b) Zhou, J.; Magomedov, N. A. J. Org. Chem. 2007, 72, 3808.

11. Padwa, A.; Flick, A.; Lee, H. I. Org. Lett. 2005, 7, 2925.

12. (a) Ollis, W. D.; Stanforth, S. P.; Ramsden, C. A. Tetrahedron 1985, 41, 2239. (b) Padwa, A.; Coats. S. J.; Semones, M. A. Tetrahedron 1995, 51, 6651.

13. Potts, K. T.; Rochanapruk, T.; Padwa, A.; Coats, S. J.; Hadjiarapoglu, L. J. Org. Chem. 1995, 60, 3795.

14. (a) Kappe, T.; Golser, W.; Hariri, M.; Stadlbauer, W. Chem. Ber. 1979, 112, 1585. (b) Friedrichsen, W.; Kappe, T.; Böttcher, A. Heterocycles 1982, 19, 1083.

15. (a) Kappe, T.; Ziegler, E. Angew. Chem., Int. Ed. Engl. 1974, 13, 491. (b) Hopff, H.; Hegar, G. Helv. Chim. Acta 1961, 44, 2016. Staudinger, H.; Bereza, S. Ber. 1908, 41, 4461.

16. Carbonyl sulfide was identified by trapping in an alcoholic solution of piperidine where it formed the corresponding salt; see: Seibert, W. Angew. Chem. 1959, 71, 194.

17. Lindstrom, U. M.; Somfai, P. Chem Eur. J. 2001, 7, 94.

18. (a) Sonogashira, K.; Tohda, Y.; Hagihara, N. Tetrahedron Lett. 1975, 16, 4467. (b) Chinchilla, R.; Nájera, C. Chem. Rev. 2007, 107, 874. 
19. Trost, B. M.; Braslau, R. Tetrahedron Lett. 1989, 30, 4657.

20. Paterson, I.; Yeung, K.-S.; Smaill, J. B. Synlett 1993, 774.

21. (a) Kato, S.; Harada, H.; Morie, T. J. J. Chem. Soc., Perkin Trans. 1997, 1, 3219. (b) Nakajima, K.; Tanaka, T.; Meya, M.; Okawa, K. Bull. Chem. Soc. Jpn. 1982, 55, 3237.

22. Vedejs, E.; Klapars, A.; Warner, D. L.; Weiss, A. H. J. Org. Chem. 2001, 66, 7542.

23. Padwa, A.; Harring, S. R.; Hertzog, D. L.; Nadler, W. R. Synthesis, 1994, 993.

24. The senior author regrets that spectral data for compounds 34-43 are not presented. These compounds (i.e. 34-43) were intermediates for an eventual synthesis of $\delta$-lactam 30. Unfortunately, the reason for this omission is that the data were lost during a move of our laboratory from one location to another and inadvertently discarded during a period of my absence. Because the two junior collaborators have since left the group and are working elsewhere, it is not practical for us to repeat this work with our very limited resources. I do regret that this has happened, but do feel as though the chemistry is reliable. If anyone might be interested in preparing lactam $\mathbf{3 0}$ in the future, the details are well laid out. Under these circumstances and with the agreement of the Scientific Editor of Arkivoc, the paper is being published with this deficiency. (Editor's comment -- Please note that the special circumstances surrounding this matter will not be taken as a precedent for any future relaxation of Arkivoc's requirements for full characterization). 